\title{
Special Education Teachers' Self-efficacy Beliefs Toward Science Course
}

\author{
Yeşim Taktat Ateş, Hüseyin Ateş*, Neslihan Özbek, Özlem Afacan \\ Department of Science Education, Faculty of Education, Ahi Evran University, Kirşehir, Turkey
}

*Corresponding Author: huseyinates_38@hotmail.com

\section{ABSTRACT}

The aim of this study was to determine special education teachers' self-efficacy belief levels toward science. In the study, an explanatory mixed method was used in which quantitative and qualitative research methods were involved together. This study included both survey and case study methodology. To determine the level of special education teachers' self-efficacy beliefs toward science, the "Self-Efficacy Beliefs toward Science Scale" developed and adapted in 1990 by Riggs and Enochs was used. This scale was translated to Turkish by Bıkmaz (2004). The main data of the study were collected through a survey by 115 special education teachers in Kırşehir in Turkey during the spring semester of 2017-2018 academic year. In addition, semi-structured interviews were conducted with four special education teachers selected from the main study. When the results of the study were examined, it was seen that the teachers' level of self-efficacy beliefs toward science was at a neutral level. According to the results of qualitative data analysis, teachers stated that they felt sufficiently prepared for their science course and that they affected the competency levels of their students' performances. In addition, special education teachers stated that they experienced no problems in some subjects they experienced problems in other subjects. Special education teachers believed that if the teacher gives a lesson in accordance with students' level, he/she can have a positive impact on the student, and if the teacher likes the science course, the success of the student would increase.

KEY WORDS: special education; self-efficacy; special education teachers; science education

\section{INTRODUCTION}

$\mathbf{P}$ eople are born with individual differences. Individuals with special needs to maintain their lives independently and productively need to acquire the skills required for daily life (Idol, 2006). It is important that individuals with special needs should be completely independent to participate in social roles (Harry and Klingner, 2014). This may be possible by determining the educational needs of these individuals by considering their needs and abilities and by providing educational environments according to their own needs (Bennett, 1986; Deno, 1990; Meyer \& Rose, 2000; Wilson, 2018). Every child has the right to an education (i.e. Article 42 of the Constitution of the Republic of Turkey, 1982; First Protocol, Article 2 of the Human Rights Act of United Kingdom, 1998; The Constitution of India [Eighty-sixth Amendment], 2002 inserted Article 21-A; United Nations Convention on the Rights of the Child, 1989). Children should be provided with an education regardless of whether they are healthy or disabled. Given the fact that, the development of children with disabilities is different from the development of the other children, appropriate training should be given in accordance with their characteristics (Ashman \& Conway, 2017; Snow, 2017). Special education is essential to improve the situation of children with special needs (Ashman $\&$ Conway, 2017). Special education is the education of students with special needs given by specialist personnel in an environment that is organized according to the characteristics of disabled individuals and children (Kauffman et al., 2018).

Inclusive education is where all students are trained together. Sebba and Sachdev (1997) described inclusive education as the process of restructuring an educational institution to provide all students with an opportunity to achieve equality. From this definition, inclusive education means giving children the right to receive education in a natural environment based on equality. The underlying reason for this is to provide children with the opportunity to study in a natural environment that is not much different from the atmosphere of classes with their peers (Donovan \& Cross, 2002; Kauffman et al., 2018). Although all students are considered to have the right to be educated, there are some obstacles to the quality of education. Some of these obstacles are the inadequacy of the physical conditions of the schools, the intensity of the classes, lack of the enrichment of the classes with special educational materials, and the lack of material of the support education classrooms, as well as the lack of teachers who will provide special education (Kauffman, et al., 2018; Turnbull et al., 2013). Considering the content of these obstacles related to teachers about the success of teachers, lack of knowledge, skills, and abilities of teachers, pedagogical deficiencies, and low levels of self-efficacy beliefs related to their professions are the leading factors that significantly affect the quality of education and student achievement (Bandura, 1977). Among these factors, the level of self-efficacy beliefs of 
teachers is frequently emphasized in the literature. Considering the related literature, it has been highlighted that teachers have high or low levels of self-efficacy beliefs which affect both teachers' and students' motivations and interests toward science course (e.g. Ateş \& Saylan, 2015; Bandura, 1986; Pajares, 2002; Yildiz et al., 2018; Zajacove et al., 2005). According to Bandura (1986), the concept of self-efficacy is defined as the individual's own self-judgment on the individual's ability to perform certain tasks or duties.

\section{The Purpose and Importance of the Study}

The judgments of special education teachers' self-efficacy beliefs related to making up a shortage of special needs children constituted the basis for this study. The aim of this study was to determine the special education teachers' self-efficacy belief levels toward their science course. It is of great importance that teachers have high levels of self-efficacy beliefs to ensure that special education teachers struggle with the difficulties they face in science courses. In addition, it is important the motivation, and academic success levels of the students are kept high during the education-teaching process. Another reason for the importance of this issue is that the number of students who require special education increases every year. According to National Center for Education Statistics in United States (2009), while the number of students in need of special education between the ages of 3 and 21 was 4.1 million in 1980 (10\% of total students), this number reached 6.5 million in 2009 (13\% of total students).

Special education teachers should contribute to the development of students' knowledge, skills, attitudes, motivation, and academic achievement at all stages of the teaching process as well as in all courses. Considering the related literature, importance of science courses to provide increasing students' levels of success has been emphasized in many studies (Courtade et al., 2013; Mulvey et al., 2016; Scruggs \& Mastropieri, 2007; Steele, 2007; Vannest et al., 2009; Topping et al., 2004). In the comprehensive review of the teaching of science education courses to students with special needs, guidelines were published as science education standards by the National Research Council (1996) in the United States, and some recommendations were presented. The guidelines contain eight topics, including the nature and history of science, the world and space science, science, and technology. Similarly, in Turkey, the importance given to the subject in the science curriculum updated in 2018 was presented in two different ways (Turkish Ministry of National Education, 2018). First, the purpose of the program and its preparation are stated under the title of individual development and education programs. In addition to this, the assessment and evaluation approach of the students with special needs in the curriculum is also included. It is stated that it is not appropriate to provide only a single type of assessment and evaluation method for all students, due to the fact that, individual differences are related to the principles that guide assessment and evaluation practices in educational programs. Because of these reasons, it can be said that the curriculum is a guide in this respect. Since diversity in education is severely affected by internal and external dynamics such as individual, education level, course content, social environment, and school facilities, it is expected from teachers and education practitioners not to prioritize education programs in ensuring the effectiveness of assessment and evaluation practices. It is extremely important to decide which teaching strategies are effective in supporting the learning needs and to have high levels of self-efficacy belief in teaching this subject, along with the aims, objectives, and approaches given in the program as well as the difficulties experienced by science teachers in all levels and contexts (McGinnis, 2013).

\section{Research Questions}

There were five research questions this study sought to address. Both quantitative and qualitative research methods were used. Two of the research questions were addressed by quantitative research methods:

1. What are the levels of special education teachers' selfefficacy beliefs toward science course?

2. Is there a significant difference between the special education teachers' self-efficacy beliefs toward science course in terms of demographic variables (gender, department, history of science, and interest in special education)?

Moreover, three of them were addressed by qualitative research methods:

3. How do special education teachers feel themselves when teaching science courses in support education classroom?

4. What are the special education teachers' views about the effect of teachers' self-efficacy level on students' learning?

5. What are the special education teachers' views about the effect of teachers' self-efficacy beliefs level toward science course on the student's academic achievement?

\section{METHODS}

\section{Research Design}

To fulfill the purpose of the study, mixed method was used. Among, mixed methods, to obtain the data from the quantitative data of the study, survey methodology is frequently used in the social sciences (Muijs, 2004). Within the scope of this study, the study was carried out with a cross-sectional study method. In a cross-sectional study, data were collected over a sample determined from a predetermined population (Fraenkel et al., 2012). In cases where only one data form obtained by quantitative or qualitative research methods alone in the mixed method are insufficient to reach the expected result, a more detailed analysis of the study is provided (Brewer and Hunter, 1989; Tashakkori et al., 1998).

\section{Sample}

The main data of the study were collected through a survey by 115 special education teachers $\left(\mathrm{N}_{\text {female }}=72, \mathrm{~N}_{\text {male }}=43\right.$, $\mathrm{M}_{\text {age }}=34.42$ ) in Kırşehir in Turkey during the spring semester of 2017-2018 academic year. During the selection of the sample included in the study, convenience sampling was used. 
Eighty of the teachers participating in the study work in public schools under the Turkish Ministry of National Education, while 35 work in private education institutions. Descriptive statistical data for demographic variables are given in Table 1.

\section{Selected Study Group for Collecting Qualitative Data}

To collect the qualitative data of the study, semi-structured interviews were conducted randomly with four special education teachers who were selected from the quantitative data of the study. In order not to explain the identities of the teachers in the study group, codes were given to them (T1, $\mathrm{T} 2, \mathrm{~T} 3$, and $\mathrm{T} 4)$.

\section{Quantitative Data Collection Tool}

Within the scope of this study, the "Personal Information Form," including information such as gender, age, professional experience, high school, university, and department, and the "Self-Efficacy Beliefs toward Science Scale" developed in 1990 by Riggs and Enochs and adapted to Turkish by B1kmaz (2004) were used. This scale was prepared as a 5-point Likert type from "strongly agree" to "strongly disagree." The scale consists of 20 items and two sub-dimensions: "Efficacy belief" and "outcome expectation."

\section{Qualitative Data Collection Tool Interview form}

The semi-structured interview form was used during the collection of qualitative data. Data were collected with four teachers working in Kırşehir in Turkey. Within the scope of the study, two questions were asked to the teachers during the interview. Questions asked to teachers are listed below.

\begin{tabular}{lcc}
\hline $\begin{array}{l}\text { Table 1: Descriptive statistical data for demographic } \\
\text { variables }\end{array}$ & ( \\
\hline Demographic variables & 72 & \\
\hline Gender & 43 & 62.61 \\
$\quad$ Female & & 37.39 \\
Male & 80 & \\
Institutions teachers work & 35 & 69.57 \\
Public school & & 30.43 \\
Private school & & \\
Mean age & 13 & \\
Department teachers graduated & 57 & 11 \\
Pre-school teaching & 25 & 50 \\
Elementary school teaching & 20 & 22 \\
Special education teaching & 11 Years & 17 \\
Other & & \\
Occupational experience & 23 & 20.0 \\
Reason of choosing the department & 27 & 23.5 \\
Environmental expectations & 4 & 3.5 \\
Professional expectation & 29 & 25.2 \\
Socio-economic status & 32 & 27.8 \\
Personality & 93 & \\
Other & 22 & \\
Giving course related to science during undergraduate education & \\
Yes & & \\
No & & \\
\hline
\end{tabular}

1. Do you feel adequate yourself during teaching the science course in support education classroom?

2. Do you think the teachers' self-efficacy level toward science teaching affect the student?

\section{Validity and reliability of data}

The reliability study was conducted in a pilot study with 427 pre-service teachers who were studied in the Department of Early Childhood Education and Primary School Teaching, resulted in a Cronbach's alpha reliability coefficient of the scale as $=0.78$. The results indicated that internal consistency value is acceptable (Pallant, 2005).

\section{Data Collection}

The data were collected from special education teachers by the researchers after the permission received from the Directorate of National Education of Kırşehir. Before the administration of the questionnaires, all participants were given and signed a consent form confirming that they volunteered to participate in this study. The duration of application of the study was about $10 \mathrm{~min}$ in quantitative part, and each interview lasted about 30 min during the semi-structured interview.

\section{Analysis of Quantitative and Qualitative Data}

The analysis of the quantitative data obtained within the scope of the study was analyzed with SPSS version 22 program. Factor analysis, inferential statistics, and descriptive analysis were used to analyze these data. During the descriptive analysis of the data in the study, central tendency measurements such as mode, median, percentage, frequency, and standard deviation were used. In addition, the number of the group formula (Ranj/Group Number) formula to determine the intervals by the descriptive analysis of the interpretation was made. In addition, independent samples t-test and one-way ANOVA were used during inferential statistics. Some analyses were performed before applying exploratory factor analysis. KMO values of these analyzes were found to be 0.744 (Kaiser, 1974) and Barlett value was found as significant (Bartlett, 1954) $\left(\mathrm{X}^{2}=764.996, \mathrm{df}=171, \mathrm{p}<0.05\right)$. These results indicate that the data were appropriate for factor analysis (Pallant, 2005). According to the results of the factor analysis, the two dimensions (Efficacy Beliefs and Outcome Expectation) were found in which the eigenvalue value was over 1, and the results explained $39.98 \%$ of the total variance. Each of the two subdimensions obtained as a result of the factor analysis contains ten items. Data toward qualitative research were analyzed with content analysis.

\section{FINDINGS}

\section{Findings toward Quantitative Analysis \\ Special education teachers' self-efficacy belief levels toward science course}

The factors, the items, and the descriptive statistical data for these items related to the self-efficacy beliefs of the special education teachers toward the science course are shown in Table 2. 
Table 2: Special education teachers' self-efficacy beliefs toward science course

\begin{tabular}{|c|c|c|c|c|c|c|c|c|c|}
\hline $\begin{array}{l}\text { Name of } \\
\text { factors }\end{array}$ & Item no & Items & M & SD & $\begin{array}{l}\text { Strongly } \\
\text { disagree }\end{array}$ & Disagree & Neutral & Agree & $\begin{array}{l}\text { Strongly } \\
\text { agree }\end{array}$ \\
\hline \multirow[t]{10}{*}{$\begin{array}{l}\text { Efficacy } \\
\text { belief }\end{array}$} & $2 *$ & $\begin{array}{l}\text { Even if I try very hard, I will not teach science as } \\
\text { well as I will most subjects. }\end{array}$ & 3.43 & 1.24 & 7.0 & 19.1 & 20.0 & 51.3 & 2.6 \\
\hline & $4^{*}$ & $\begin{array}{l}\text { I will not be very effective in monitoring science } \\
\text { experiments. }\end{array}$ & 3.37 & 1.1 & 12.2 & 11.3 & 13.9 & 47.0 & 15.7 \\
\hline & $5^{*}$ & $\begin{array}{l}\text { When a student does better than usual in science, } \\
\text { it is often because the teacher exerted a little extra } \\
\text { effort. }\end{array}$ & 3.17 & 1.26 & 6.1 & 22.6 & 27.8 & 39.1 & 4.3 \\
\hline & 7 & $\begin{array}{l}\text { The inadequacy of a student's science background } \\
\text { can be overcome by good teaching. }\end{array}$ & 3.64 & 1.13 & 6.1 & 15.7 & 27.0 & 37.4 & 13.9 \\
\hline & 11 & $\begin{array}{l}\text { The teacher is generally responsible for the } \\
\text { achievement of students in science. }\end{array}$ & 3.16 & 0.98 & 11.3 & 21.7 & 20.9 & 30.4 & 15.7 \\
\hline & 16 & $\begin{array}{l}\text { I wonder if I will have the necessary skills to teach } \\
\text { science. }\end{array}$ & 3.04 & 1.04 & 9.6 & 14.8 & 16.5 & 42.6 & 16.5 \\
\hline & 17 & $\begin{array}{l}\text { Given a choice, I will not invite the principal to } \\
\text { evaluate my science teaching. }\end{array}$ & 3.17 & 1.11 & 5.2 & 13.9 & 14.8 & 43.5 & 22.6 \\
\hline & $18^{*}$ & $\begin{array}{l}\text { When a student has difficulty understanding a } \\
\text { science concept, I will usually be at a loss as to } \\
\text { how to help the student understand it better. }\end{array}$ & 3.44 & 1.06 & 7.8 & 39.1 & 38.3 & 13.0 & 1.7 \\
\hline & 19 & $\begin{array}{l}\text { When teaching science, I will usually welcome } \\
\text { student questions. }\end{array}$ & 3.8 & 1.03 & 7.0 & 16.5 & 20.0 & 46.1 & 10.4 \\
\hline & 20 & $\begin{array}{l}\text { I do not know what to do to turn students on to } \\
\text { science. }\end{array}$ & 3.23 & 1.1 & 7.0 & 10.4 & 27.8 & 49.6 & 5.2 \\
\hline \multirow{10}{*}{$\begin{array}{l}\text { Outcome } \\
\text { Expectation }\end{array}$} & 1 & I will continually find better ways to teach science. & 3.23 & 1.02 & 5.2 & 20.9 & 31.3 & 38.3 & 4.3 \\
\hline & 3 & $\begin{array}{l}\text { I know t: a steps necessary to teach science } \\
\text { concepts effectively. }\end{array}$ & 3.13 & 1.01 & 3.5 & 10.4 & 16.5 & 57.4 & 12.2 \\
\hline & 6* & I will generally teach science ineffectively. & 3.42 & 1.21 & 1.7 & 15.7 & 26.1 & 46.1 & 10.4 \\
\hline & 8* & $\begin{array}{l}\text { The low science achievement of some students } \\
\text { cannot generally be blamed on their teachers. }\end{array}$ & 2.62 & 0.87 & 3.5 & 20.9 & 20.0 & 47.0 & 8.7 \\
\hline & 9 & $\begin{array}{l}\text { When the science grades of students improve, } \\
\text { it is often due to their teacher has found a more } \\
\text { effective teaching approach. }\end{array}$ & 3.37 & 1.09 & 1.7 & 16.5 & 24.3 & 54.8 & 2.6 \\
\hline & 10 & $\begin{array}{l}\text { I understand science concepts well enough to be } \\
\text { effective in teaching elementary science. }\end{array}$ & 3.36 & 0.98 & 5.2 & 30.4 & 24.3 & 34.8 & 5.2 \\
\hline & 12 & $\begin{array}{l}\text { Students' achievement in science is directly related } \\
\text { to their teacher's effectiveness in science teaching. }\end{array}$ & 3.64 & 0.95 & 8.7 & 17.4 & 33.0 & 30.4 & 10.4 \\
\hline & 13 & $\begin{array}{l}\text { If parents comment that their child is showing more } \\
\text { interest in science at school, it is probably due to } \\
\text { the performance of the child's teacher. }\end{array}$ & 3.48 & 0.94 & 5.2 & 14.8 & 23.5 & 43.5 & 13.0 \\
\hline & 14 & $\begin{array}{l}\text { I will find it difficult to explain to students why } \\
\text { science experiments work. }\end{array}$ & 3.37 & 1.02 & 3.5 & 10.4 & 12.2 & 50.4 & 23.5 \\
\hline & 15 & $\begin{array}{l}\text { I will typically be able to answer students' science } \\
\text { questions. }\end{array}$ & 3.4 & 0.86 & 7.0 & 19.1 & 28.7 & 33.9 & 11.3 \\
\hline
\end{tabular}

According to the results of descriptive analysis, the average of special education teachers in terms of self-efficacy beliefs toward science courses was 3.33 out of 5 . When the results are examined in terms of items, $74 \%$ of special education teachers reported that they would generally welcome students' questions while teaching science courses $(\mathrm{M}=3.80)$. However, many teachers $(70 \%)$ think that students' success in science courses is directly related to teachers' effectiveness in science teaching $(\mathrm{M}=3.64)$. In addition, most of the teachers in the study (66\%) think that the shortcomings of a student can be solved with good science teaching $(\mathrm{M}=3.64)$.
Investigation of the difference between special education teachers' self-efficacy beliefs toward science course in terms of demographic characteristics

To examine the differences between the special education teachers' self-efficacy beliefs in terms of demographic characteristics, analyses were conducted based on the variables of interest in gender, education department, reasons for choosing this department, residential area, science background, and interest toward special education. Independent samples t-test analysis were conducted to examine the difference between special education teachers' self-efficacy beliefs about 
science courses. The findings of the analysis are presented in Table 3.

According to Table 3, there was no significant difference between special education teachers' self-efficacy beliefs toward science courses in terms of gender $[\mathrm{t}(113)=1.492$, $\mathrm{p}>0.05]$.

One-way ANOVA was conducted to examine the difference between special education teachers' self-efficacy beliefs toward science courses. The findings of the analysis are presented in Table 4.

According to Table 4, there was a significant difference between the self-efficacy beliefs of the special education teachers toward science course $[\mathrm{F}(3-114)=3.182, \mathrm{p}<0.05]$. When this difference was examined, the highest average belonged to people who graduated from elementary school teaching $(\mathrm{M}=3.49)$ and the lowest to those people who marked as others $(M=3.08)$. In addition, the average of teachers who graduated from special education $(\mathrm{M}=3.38)$ was higher than teachers who graduated from elementary school teaching and lower than those who graduated from pre-school teaching $(\mathrm{M}=3.34)$. To measure the magnitude of this difference, the effect size was examined and found to be 0.07 . This value shows that the difference has a medium size effect (Cohen, 1988). Data on means are shown in Table 5.

Independent samples t-test analysis was conducted to examine the difference between the special education teachers'

Table 3: Investigation of the difference between special education teachers' self-efficacy beliefs toward science course in terms of gender

\begin{tabular}{lcccccc}
\hline Group & $\mathbf{n}$ & $\mathbf{d f}$ & $\mathbf{M}$ & $\mathbf{S D}$ & $\mathbf{T}$ & $\mathbf{p}$ \\
\hline Female & 72 & 71 & 3.44 & 0.52 & 1.49 & 0.139 \\
Male & 43 & 42 & 3.29 & 0.53 & & \\
Total & 115 & 113 & & & & \\
\hline
\end{tabular}

\begin{tabular}{|c|c|c|c|c|c|c|}
\hline $\begin{array}{l}\text { Source of } \\
\text { variance }\end{array}$ & $\begin{array}{l}\text { Sum of } \\
\text { squares }\end{array}$ & df & $\begin{array}{c}\text { Mean } \\
\text { squares }\end{array}$ & $\mathbf{F}$ & $\mathbf{p}$ & $\eta^{2}$ \\
\hline Between groups & 2.52 & 3 & 0.84 & 3.18 & 0.027 & 0.07 \\
\hline Within groups & 29.34 & 111 & 0.26 & & & \\
\hline Total & 31.87 & 114 & & & & \\
\hline
\end{tabular}

Table 5: Self-efficacy score average in terms of department teachers graduated

\begin{tabular}{lcc}
\hline Department & M & SD \\
\hline Pre-school teaching & 3.34 & 0.53 \\
Elementary school teaching & 3.50 & 0.52 \\
Special education & 3.38 & 0.44 \\
Others & 3.09 & 0.58 \\
\hline
\end{tabular}

self-efficacy beliefs in terms of having a science background or not. The findings of the analysis are presented in Table 6 .

According to Table 6, there was no significant difference between the special education teachers' self-efficacy beliefs in terms of having $a$ science background or not $[\mathrm{t}(113)=0.087$, $\mathrm{p}>0.05]$.

Independent samples t-test analyses were conducted to examine the difference between special education teachers' self-efficacy beliefs toward science courses (interest in special education subject). The findings of the analysis are presented in Table 7.

According to Table 7, there was no significant difference between the special education teachers' self-efficacy beliefs toward science course in terms of interest in special education subject [t(113) $=0.255, \mathrm{p}>0.05]$.

\section{Findings Related to Qualitative Analysis}

Do special education teachers see theirselves qualified when they teach science subjects?

In the scope of the study, first of all, it was asked to do special education teachers see themselves qualified to teach science subjects. When the answers were examined, the teachers T1 and $\mathrm{T} 2$ believed that they were qualified, while $\mathrm{T} 3$ and $\mathrm{T} 4$ stated that they felt unqualified in terms of teaching the science. They also stated that they felt unqualified in terms of content knowledge. In addition, special education teachers stated that they experienced problems in certain subjects, which were hard for them, and they also stated that they could easily teach not difficult science subjects. An example of teachers' answers to this question is shown below:

I graduated from department of primary school teaching. Even if I graduated from special education teaching, it won't be problem. We became a special education teacher with the certificate. If I am a special education teacher, I do not think that I can be useful to the mainstreaming students in the science education field. In addition, my benefit to students depends on students'academic performance. (T1)

Table 6: Difference between the special education teachers' self-efficacy beliefs in terms of having a science background or not

\begin{tabular}{lcccccc}
\hline Group & $\mathbf{n}$ & $\mathbf{d f}$ & $\mathbf{M}$ & $\mathbf{S D}$ & $\mathbf{t}$ & $\mathbf{p}$ \\
\hline Yes & 93 & 92 & 3.38 & 0.54 & 0.087 & 0.931 \\
No & 22 & 21 & 3.39 & 0.46 & & \\
Total & 115 & 113 & & & & \\
\hline
\end{tabular}

Table 7: Difference between special education teachers' self-efficacy beliefs toward science course (interest in special education subject)

\begin{tabular}{lcccccc}
\hline Group & $\mathbf{n}$ & $\mathbf{d f}$ & $\mathbf{M}$ & $\mathbf{S D}$ & $\mathbf{t}$ & $\mathbf{p}$ \\
\hline Yes & 50 & 49 & 3.39 & 0.53 & 0.255 & 0.799 \\
No & 65 & 64 & 3.37 & 0.52 & & \\
Total & 115 & 113 & & & & \\
\hline
\end{tabular}




\section{Qualification in the planning and preparation of science} courses

Special education teachers were asked about their qualifications in the planning and preparation phase of the science course related to the previous question. According to the answers from the teachers, they stated that they felt sufficient about their planning and preparation, but they experienced problems related to the applicability of the planning and that the students had problems about what subjects they should learn. An example of teachers' answers to this question is shown below:

I can make an appropriate plan and preparation, but I can have difficulty applying to it. (T1)

\section{Qualification related to experimentation in science courses}

Special education teachers were asked whether they felt sufficient about the ability to set up and implement experiments while teaching science. When the answers of the teachers were examined, teachers T1 and T3 stated that they did not give much place to experimenting as they were giving priority to the skills students need to learn for daily life. T2 and T4 stated that they could prepare experiments based on the level and competence of the students and emphasized the experiments that would meet the needs of the students. For example:

I think I can, because I think I'm enough in that sense. If the subject I teach is intertwined with nature and contains an experiment that I will teach with constructivism, I try to prepare it to help the students I will teach. I'll try to do as much as I can. (T1)

\section{Teachers' opinions related to eliminating failure of} students with effective teaching method

Teachers' opinions related to eliminating failure of students with effective teaching methods were given. When the answers were examined, teachers have emphasized that methods and materials should be provided so that students achieve success. Teachers stated that students can be successful in determining the activities that could be applied is provided, three-dimensional materials will provide success, simple observations and experiments, visual materials, fun material use, experiment, and observation that the methods can be effective in providing success. However, it was among the answers emphasized by the teachers that it may be beneficial to cooperate with science teachers during the construction of these activities, as evidenced below:

I don't think the gaps will be gone. I had a student who was very interested in music. I taught Turkish lesson and Mathematics lesson with music. If students are interested in science, you can give Turkish and mathematics together with science. It's important to catch interest. (T2)

Teachers' self-efficacy status in solving learning problems of students toward science course

It was questioned whether or not teachers found themselves sufficient in solving the students' problems related to science learning. When the answers were examined, T1 and T2 felt adequate, and T3 and T4 stated that they did not feel sufficient. Teachers who saw themselves sufficient think that if they understood the level of the student, success could be achieved, and the students' needs could be benefited if it was determined. Teachers who felt inadequate stated that this was due to lack of experience and stated that they did not think that the deficiencies related to learning problems would disappear completely. An example of teachers' answers to this question is below:

For that moment, I may not be able to solve it. But I can solve problems over time what this child needs, what kind of teaching method can benefit from the technique. (T1)

\section{The effect of teacher's self-efficacy belief on students'} science learning

In the second question, the teachers were asked whether their self-efficacy beliefs toward science teaching affected the students. When the answers received were examined, special education teachers believed that the teacher could benefit if they understood the level of the students and if teachers like the science, they would positively affect the success of the students. For example:

Affects positively. Because the teacher enjoys doing something that he/she likes. She/he will make a kid happy. This is also the case in society. You can enjoy sharing something you love with someone. And when you transfer it students, they also like. (T2)

The effect of special education teachers' self-efficacy level toward science course on students' academic achievement

Questions were asked about the effect of the special education teacher's self-efficacy level toward science courses on students' academic success. When the answers were examined, special education teachers stated that if teachers had high self-efficacy beliefs toward science the students could achieve success in their academics and do their homework. They stated that the high level of self-efficacy of the teacher would positively affect students' academic achievement, as students' self-confidence would increase. However, they expressed that if the teacher was reluctant; the student might be reluctant and would have a negative effect on their academic success, as shown below:

If we can pass that emotion to the child, we will have a positive impact on in terms of child doing homework if we can keep their self-efficacy beliefs high. (T3)

\section{The effect of self-efficacy level of the special education} teacher toward science course on the social acceptance of students in the classroom

It was asked how special education teachers' self-efficacy belief levels affect students' social acceptance in the classroom. When the answers received were examined, special education teachers stated that if they learn something in the lesson, students would believe that they would benefit from it and increase their social acceptance. In addition, they stated that if the teacher's self-efficacy beliefs level toward science was 
high, the academic success of the student would be positively affected and the social acceptance of the students will be positively affected, and the student's self-confidence will be increased, see below:

...the increase in academic achievement of the student may affect the relationship of friends in the classroom by removing the child from the inclusive student profile. (T2)

\section{DISCUSSION, CONCLUSIONS, AND RECOMMENDATIONS}

Quantitative research methods and qualitative research methods were used to obtain the objectives of the study.

\section{Results of Quantitative Data of Study}

When the results of the study were examined, the average of the 20 items under the "Efficacy Belief" and "Outcome Expectation" dimensions was 3.33 out of 5 . According to this result, it is seen that teachers' self-efficacy belief level towards science is at an undecided level. Nevertheless, most of the teachers stated that they would generally welcome the students' questions while teaching science. In addition, the success of the students in the science course is directly related to the effectiveness of teachers in science teaching, and students' deficiencies in science could be solved with good instructional strategies.

When the related studies about the subject were examined, it has been seen that the number of studies on the special education teachers' or pre-service special education teachers' self-efficacy beliefs toward science is limited in the literature (e.g., Aydoğan, 2016). According to the results of the study conducted by Aydoğan (2016), it was found that the self-efficacy beliefs of pre-service special education teachers about science teaching were 3.46 out of 5 . In the literature, the number of studies examining special education teachers' self-efficacy beliefs on science teaching is limited. About $11 \%$ of the special education teachers in this study graduated from pre-school teaching and $50 \%$ graduated from the primary school teaching department. For this reason, the results of the studies examining the selfefficacy beliefs of pre-school and classroom teacher teachers or pre-service teachers toward science in Turkey and other countries are also discussed (e.g., Bayraktar, 2011; Bergman \& Morphew, 2015; Çorapç1gil et al., 2016; Davis et al., 2006; Flores, 2015; Gökgül, 2013; Hechter, 2011; Kazempour, 2014; Kazempour \& Sadler, 2015; Knaggs \& Sondergeld, 2015; Kurtuluş \& Çavdar, 2010; Serin \& Bayraktar, 2015; Tortop \& Çeker, 2014; Wingfield et al., 2000; Y1lmaz, 2014). Among studies abroad, in a study conducted by Bergman and Morphey (2015), a pre-service elementary teacher education program at a Midwestern University in USA was arranged to contain a new science content course purposed. A pre-/post-assessment study method was used (154 preservice elementary teachers) completing a Science Teaching Efficacy Belief Instrument for pre-service teachers (STEBI-B) (Bleicher, 2004; Enochs \& Riggs, 1990) at the beginning and end of the course. Results between pre- $(\mathrm{M}=35.29, \mathrm{SD}=4)$ and post-assessments $(\mathrm{M}=$ $37.47, \mathrm{SD}=4.71)$ involve statistically significant enhanced in both sub-scales (Personal Science Teaching Efficacy Beliefs and Science Teaching Outcome Expectancy) in STEBI-B scale $(\mathrm{t}(153)=4.09, \mathrm{p}<0.001, \alpha=0.05)$. Implications contain the role of a science content course specifically prepared for pre-service elementary teachers, as well as suggestions for enhancements and collaboration among faculty in natural sciences and education. In a study conducted by Flores (2015), 30 pre-service elementary teachers from a 4-year university in Southern California in USA enrolled in a field-based science course were involved at a public elementary school for coursework and for teaching practice with them. During the first 10 weeks, pre-service elementary teachers concentrated on placing conceptual understanding of science content and pedagogical methods through innovational curriculum development and other course assignments. Teaching practice with $5^{\text {th }}$-grade students at the elementary school occurred over a 5-week period toward the end of the course. After the implementation process, it was revealed that levels of pre-service teachers' personal science teaching efficacy and science teaching outcome expectancy increased significantly $(\mathrm{t}(29)=5.710, \mathrm{p}<0.05)$. Knaggs and Sondergeld (2015) conducted a study with 26 pre-service teachers who study at the departments related to early childhood $(n=21,80.8 \%)$ and middle childhood majors $(n=5,19.2 \%)$ an institution in Northwest Ohio in USA. During the implementation, researchers carried out a science course and measured the self-efficacy beliefs toward science. As a data collection tool, they used STEBI-B instrument, including two sub-scales as "personal efficacy" and "outcome expectancy." Results of the study revealed that Regarding "personal efficacy," preservice teachers' self-efficacy beliefs significantly increased from before the course $([\mathrm{M}=46.46, \mathrm{SD}=5.01]$ to after $[\mathrm{M}$ $=51.46, \mathrm{SD}=5.67] ; \mathrm{t}(25)=5.00, \mathrm{p}<0.001)$. Similarly, for outcome expectancy sub-scale, their self-efficacy beliefs significantly increased from before the course $([\mathrm{M}=34.85$, $\mathrm{SD}=2.80]$ to after $[\mathrm{M}=37.12, \mathrm{SD}=3.68] ; \mathrm{t}(25)=2.27, \mathrm{p}<$ $0.05)$. Considering the studies conducted in Turkey, In Gökulu and Koç' (2016) study, classroom teachers' self-efficacy beliefs about science teaching were examined, and according to the results of the study, it was stated that the level of teachers' self-efficacy beliefs was positive. According to the results of the study conducted by Bayraktar (2011), it was concluded that the levels of pre-service classroom teachers' self-efficacy beliefs increased in parallel with the grade level. Gökgül (2013) concluded that the level of self-efficacy beliefs of the preservice classroom teachers is above the mid-level level $(\mathrm{M}=$ $3.44,57.38 \%$ ). Similarly, Meriç and Ersoy (2007) reported that the level of self-efficacy beliefs of the pre-service classroom teachers was between adequate and good $(\mathrm{M}=3.28)$. Vural and Hamurcu (2008) stated that the levels of self-efficacy beliefs of the pre-service classroom teacher increased in parallel with the grade level. When the results of the previous studies are examined, it was emphasized that the levels of self-efficacy beliefs toward science, in general, are moderate, good, or 
sufficient. Therefore, it could be said that these results in the literature are similar to the results of the current study. This means that teachers can provide more useful results in science teaching.

\section{Conclusions on the Differences between Self-Efficacy Beliefs in Terms of Demographic Characteristics}

In the second research problem of the study, the difference between the special education teachers' self-efficacy beliefs toward science in terms of demographic characteristics was examined. Among these variables, gender, department graduated from, science background, and interest in special education were involved to examine the difference between special education teachers' self-efficacy beliefs toward science courses.

\section{Conclusions Regarding the Differences between Self- efficacy Beliefs in Terms of the Department}

According to the results of the study, the difference between these variables was observed only in terms of the department. Among these departments, the teachers who graduated from primary school teaching had the highest average. In addition, teachers who graduated from special education teaching had a higher average than pre-school teaching. The lowest average belonged to teachers who graduated from other departments. According to the results of the study on the subject, in the literature, it was seen that the results of the studies emerged in favor of primary school teachers or pre-service primary school teachers in the studies in which the primary school teachers were compared with other teachers (Kurtuluş \& Çavdar, 2010). As in the literature, the reason of this study is that why teachers who graduated from the classroom teaching department have higher levels of self-efficacy beliefs toward science than the ones who graduated from pre-school and special education is can be that they are interested in science during their undergraduate education and after graduation. In the primary school and secondary school curricula updated in 2018, there are also topics related to science within the scope of the life science lesson, which is one of the courses that classroom teachers teach. For example, environmental awareness, healthy living, plant breeding, and animal feeding, contributing to the recycling of consumed substances and the effects of the shape and movements of the world on human life are the subjects related to science and are included in the scope of life sciences course. In addition, in updated teacher education curriculum in 2018, pre-service primary school teachers receive many courses related to science during their undergraduate education. These courses include environmental education, basic science in primary school, science laboratory applications, and science teaching. For all these reasons, the fact that the level of selfefficacy beliefs of primary school teachers toward science is higher than other departments supports the current study.

\section{Conclusions on the Differences between Self-efficacy} Beliefs in Terms of Gender

In previous studies that examined the effect of other independent variables on self-efficacy beliefs, similar results were observed in this study. In many studies, it was seen that there was no significant difference in gender of participants in terms of self-efficacy beliefs toward science courses (Gökulu \& Koç, 2016; Meriç \& Ersoy, 2007). For example, in a study conducted by Gökulu and Koç (2016), the effect of gender on the self-efficacy of classroom teachers who teach special education courses on science was examined, and it was found that there was no significant difference.

\section{Results of Qualitative Data of Study}

In this study, together with the quantitative applications, special education teachers' views, about self-efficacy beliefs toward science were taken in semi-structured interviews. Among these views, questions were asked about the self-efficacy beliefs levels of the special education teachers and the effect of the teacher's self-efficacy level toward the science course on students' success. Special education teachers stated that they experienced problems in certain subjects and subjects, which were hard for them, and they also stated that they could easily teach easy science subjects. Teachers who feel themselves sufficient think that if they understood the level of the student, success could be achieved, and the student's needs could be benefited if it is determined. Teachers who feel inadequate stated that they were due to lack of experience and stated that they did not think that the deficiencies related to learning problems would disappear completely.

\section{SUGGESTIONS}

Considering the limitations of the study including limited number of teachers, data collection tools and time, the following recommendations can be made:

\section{Toward Research to be Conducted}

- This study was conducted to determine the level of special education teachers' self-efficacy beliefs toward science. The application should be repeated in different provinces and districts, and the results could be more reliable.

- Interviews could be conducted with the students' parents since they should be part of students' education.

\section{Toward Application}

- In the support education classrooms, simple sets of science material can be provided.

- The data of this study were collected in a single time period.

- In subsequent studies, data collection time may be longer.

\section{ACKNOWLEDGMENTS}

- This study was obtained from the first author's master thesis and supported by the Kırşehir Ahi Evran University Scientific Research Projects Coordination Unit. Project Number: EGT.A4.17.016

- A part of this study was presented as oral presentation in " $3^{\text {rd }}$ International Congress on Education Sciences and Learning Technology" in Athens/Greece between 13 and $19^{\text {th }}$ of November 2017. 


\section{REFERENCES}

Ashman, A.F., \& Conway, R.N. (2017). Cognitive Strategies for Special Education: Process-based Instruction. New York: Routledge.

Ateş, H., \& Saylan, A. (2015). Investigation of pre-service science teachers' academic self-efficacy and academic motivation toward biology. International Journal of Higher Education, 4(3), 90-103.

Aydoğan, H. (2016). The Self-efficacy Beliefs Towards the Teaching of Science of Special Education (Mental Retardation) Teacher Candidates. Unpublished Master Thesis. Aydın, Turkey Adnan: Menderes University, Institute of Social Sciences.

Bandura, A. (1977). Self-efficacy: Toward a unifying theory of behavioral change. Psychological Review, 84(2), 191-215.

Bandura, A. (1986). Social Foundations of thought and Action: A Social Cognitive Theory. Englewood Cliffs, NJ: Prentice-Hall.

Bartlett, M.S. (1954). A note on the multiplying factors for various chi square approximations. Journal of the Royal Statistical Society, 16, 296-298.

Bayraktar, S. (2011). Turkish preservice primary school teachers' science teaching efficacy beliefs and attitudes toward science: The effect of a primary teacher education program. School Science and Mathematics, 111(3), 83-92.

Bennett, C.I. (1986). Comprehensive Multicultural Education: Theory and Practice. Boston, MA: Allyn and Bacon.

Bergman, D.J., \& Morphew, J. (2015). Effects of a science content course on elementary preservice teachers' self-efficacy of teaching. Science Journal of College Science Teaching, 44(3), 73-81.

Bıkmaz, F.H. (2004). Sınıf öğretmenlerinin fen öğretiminde öz-yeterlik inancı ölçeğinin geçerlik ve güvenirlik çalışması [The validity and reliability study of the self-efficacy belief scale in science teaching of classroom teachers]. Milli Eğitim Dergisi, 31(161), 172-180.

Bleicher, R.E. (2004). Revisiting the STEBI-B: Measuring self-efficacy in preservice elementary teachers. School Science and Mathematics, 104, 383-391.

Brewer, J., \& Hunter, A. (1989). Multimethod Research: A Synthesis of Styles. Thousand Oaks, CA: Sage Publications, Inc.

Cohen, J. (1988). Statistical Power Analysis for the Behavioral Sciences. $2^{\text {nd }}$ ed. Hillsdale, NJ: Erlbaum.

Çorapçıgil, A., Hayal, M.A., \& Aydın, E. (2016). A phenomenological perspective of candidate classroom teachers' self-efficacy beliefs for science teaching. Turkish Studies, 11(9), 209-226.

Courtade, G.R., Spooner, F., \& Browder, D.M. (2007). Review of studies with students with significant cognitive disabilities which link to science standards. Research and Practice for Persons with Severe Disabilities, 32, 43-49.

Davis, E.A., Petish, D., \& Smithy, J. (2006). Challenges new science teacher's face. Review of Educational Research, 76(4), 607-652.

Deno, S.L. (1990). Individual differences and individual difference: The essential difference of special education. The Journal of Special Education, 24(2), 160-173.

Donovan, M.S., \& Cross, C.T. (2002). Minority Students in Special and Gifted Education. Washington, DC: National Academies Press.

Flores, I.M. (2015). Developing preservice teachers' self-efficacy through field-based science teaching practice with elementary students. Research in Higher Education Journal, 27, 1-19.

Fraenkel, J.R., Hyun, H.H., \& Wallen, N.E. (2012). The Research Problem. How to Design and Evaluate Research in Education. $8^{\text {th }}$ ed. New York: McGraw Hill.

Gökgül, S. (2013). Relation between Science and Technology Self Efficacy Beliefs and Attitudes Toward Science and Technology of Students in Primary School Teaching Department (Abant İzet Baysal University). Unpublished Master Thesis. Bolu, Turkey: Abant İzzet Baysal Üniversitesi, Institute of Education Sciences.

Gökulu, A., \& Koç, G. (2016). Elementary teacher's self-efficacy beliefs regarding science teaching lesson and opinions. The Journal of Academic Social Science Studies, 43, 383-396.

Harry, B., \& Klingner, J. (2014). Why are so Many Minority Students in Special Education? New York: Teachers College Press.

Hechter, R.P. (2011). Changes in preservice elementary teachers' personal science teaching efficacy and science teaching outcome expectancies: The influence of context. Journal of Science Teacher Education, 22(2),
$187-202$.

Idol, L. (2006). Toward inclusion of special education students in general education: A program evaluation of eight schools. Remedial and Special Education, 27(2), 77-94.

Kaiser, H.F. (1974). An index of factorial simplicity. Psychometrika, 39(1), 31-36.

Kauffman, J.M., Hallahan, D.P., Pullen, P.C., \& Badar, J. (2018). Special Education: What it is and why we need it. London: Routledge.

Kazempour, M. (2014). I can't teach science! A case study of an elementary pre-service teacher's intersection of science experiences, beliefs, attitude, and self-efficacy. International Journal of Environmental and Science Education, 9(1), 77-96.

Kazempour, M., \& Sadler, T.D. (2015). Pre-service teachers' science beliefs, attitudes, and self-efficacy: A multi-case study. Teaching Education, 26(3), 247-271.

Knaggs, C.M., \& Sondergeld, T.A. (2015). Science as a learner and as a teacher: Measuring science self-efficacy of elementary preservice teachers. School Science and Mathematics, 115(3), 117-128.

Kurtuluş, N., \& Çavdar, O. (2010). Self-efficacy beliefs of teacher candidates towards science teaching, Education Sciences, 5(3), 1302-1315.

McGinnis, J.R. (2013). Teaching science to learners with special needs Theory Into Practice, 52(1), 43-50.

Meriç, G., \& Ersoy, E. (2007). The perceptions of the fourth class students of classroom teachers' education program at science instruction related to the proficiency levels. Mersin University Journal of Education Faculty, $3(1), 51-62$.

Meyer, A., \& Rose, D.H. (2000). Universal design for individual differences. Educational Leadership, 58(3), 39-43.

Muijs, D. (2004). Introduction to Quantitative Research. Doing Quantitative Research in Education with SPSS. Thousand Oaks, CA: SAGE.

Mulvey, B.K., Chiu, J.L., Ghosh, R., \& Bell, R.L. (2016). Special education teachers' nature of science instructional experiences. Journal of Research in Science Teaching, 53(4), 554-578.

National Center for Educational Statistics. (2009). Table 50. Children 3 to 21 Years Old Served under Individuals with Disabilities Education Act, Part B, by Type of Disability: Selected Years, 1976-1977 through 20072008. Available from: https://www.nces.ed.gov/programs/digest/d09/ tables/dt09_050.asp. [Last accessed on 2019 Aug 17].

National Research Council. (1996). National Science Education Standards. Washington, DC: National Academy Press.

Pajares, F. (2002). Overwiev of Social Cognitve Theory and Self-efficacy. Available from: http://www.des.emory.edu/mfp/eff.html. [Last accessed on 2007 Jul 21].

Pallant, J. (2005). SPSS Survival Guide. Crow's Nest, NSW: Allen and Unwin.

Scruggs, T.E., \& Mastropieri, M.A. (2007). Science learning in special education: The case for constructed versus instructed learning. Exceptionality, 15(2), 57-74.

Sebba, J., \& Sachdev, D. (1997). What Works in Inclusive Education? Available from: https://www.researchgate.net/publication/260798275 what_works_in_inclusive_education_-_summary_the_'what_works' series. [Last accessed on 2019 Aug 17].

Serin, M.K., \& Bayraktar, S. (2015). An examination of candidate classroom teachers' science teaching efficacy beliefs according to locus of control. Kafkas University Journal of the Institute of Social Sciences, 16, 51-71.

Snow, C.E. (2017). Issues in the study of input: Finetuning, universality, individual and developmental differences, and necessary causes. In: Fletcher, P., \& MacWhinney, B. (Eds.), The Handbook of Child Language. London: Wiley-Blackwell. p179-193.

Steele, M. (2007). Helping middle school students with learning disabilities pass the federally mandated science tests: Science instruction, study skills, and test-taking strategies. Science Scope, 31, 74-80.

Tashakkori, A., Teddlie, C., \& Teddlie, C.B. (1998). Mixed Methodology: Combining Qualitative and Quantitative Approaches. Vol. 46. Thousand Oaks, CA: SAGE.

The Constitution of India. (2002). Article 21-A. Available from: https://www. $\mathrm{mhrd} . g o v . i n / s i t e s / u p l o a d \_f i l e s / \mathrm{mhrd} /$ files/upload_document/amend86. pdf. [Last accessed on 2019 Sep 26].

The Constitution of the Republic of Turkey. (1982). Article 42. Available from: https://www.tbmm.gov.tr/anayasa/anayasa_2018.pdf. [Last 
accessed on 2019 Sep 26].

The Human Rights Act. (1998). First Protocol, Article 2. Available from: https://www.equalityhumanrights.com/en/human-rights/human-rightsact. [Last accessed on 2019 Sep 26].

Topping, K.J., Peter, C., Stephen, P., \& Whale, M. (2004). Cross-age peer tutoring of science in the primary school: Influence on scientific language and thinking. Educational Psychology, 24(1), 57-75.

Tortop, H.S., \& Çeker, C. (2014). Examining of relation of pre-service teachers' self-efficacy of science teaching between self-regulated learning skills. Dicle University Journal of Ziya Gökalp Faculty of Education, 22, 168-184.

Turkish Ministry of National Education. (2018). Science Course Curriculum, Primary and Middle School $3^{r d}, 4^{\text {th }}, 5^{\text {th }}, 6^{\text {th }}, 7^{\text {th }}$, and $8^{\text {th }}$ Grades. Ankara: Ministry of National Education.

Turnbull, A.P., Turnbull, H.R., Wehmeyer, M.L., \& Shogren, K.A. (2013). Exceptional Lives: Special Education in Today's Schools. Columbus, $\mathrm{OH}$ : Merrill.

United Nations. (1989). Convention on the Rights of the Child. Available from: https://www.ec.europa.eu/anti-trafficking/legislation-and-caselaw-international-legislation-united-nations/united-nations-conventionrights_en. [Last accessed on 2019 Sep 26].

Vannest, K.J., Mason, B.A., Brown, L., Dyer, N., Maney, S., \& Adiguzel, T. (2009). Instructional settings in science for students with disabilities:
Implications for teacher education. Journal of Science Teacher Education, 20(4), 353-363.

Vural, D.E., \& Hamurcu, H. (2008). Preschool teacher candidates' selfefficacy beliefs regarding science teaching lesson and opinions about science. Elementary Education Online, 7(2), 456-467.

Wilson, J.D. (2018). Student Learning in Higher Education. London: Routledge.

Wingfield, M., Nath, J.L., Freeman, L., \& Cohen, M. (2000). The Effect of Site-based Preservice Experiences on Elementary Social Studies, Language Arts, and Mathematics Teaching Self-efficacy Beliefs. New Orleans, LA: Paper Presented at the Annual Meeting of the American Educational Research Association.

Yildiz, A., Baltaci, S., \& Kuzu, O. (2018). The investigation of students'cognitive and metacognitive competencies according to different variables. European Journal of Education Studies, 4(10), 81-98.

Y1lmaz, M. (2014). The Relationship Between Teacher Candidates' Learning Styles and their Conceptions about Teaching and Learning and their Science Teaching Efficacy Beliefs. Unpublished Master Thesis. Bolu, Turkey: Abant İzzet Baysal Üniversitesi, Institute of Education Sciences.

Zajacove, A., Lynch, S.M., \& Espenshade, T.J. (2005). Self-efficacy, stress, and academic success in college. Research in Higher Education, 46(6), $677-706$ 